\title{
A CONCEPÇÃO DE MASSA EM SOCIOLOGIA DA COMUNICAÇÃO: TEORIA E IDEOLOGIA
}

\author{
COHN, Gabriel. \\ Sociologia da comunicação: teoria e ideologia. \\ Petrópolis-RJ: Vozes, 2014. 203 p. (Coleção Sociologia). \\ POR \\ Tiago Eloy Zaidan ${ }^{1}$
}

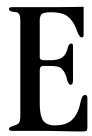
m 1895, o psicólogo e sociólogo francês Gustave Le Bon (1841-1931) apresentou sua visão pessimista, para não dizer conservadora, de multidão e massa. Na ocasião, os dois conceitos foram usados de forma indistinta. Ao versar instigantemente sobre as psicologias das massas, Le Bon diferiu 0 comportamento do homem, quando isolado, do comportamento do sujeito, quando inserto em um aglomerado.

$\mathrm{Na}$ condição de parte de uma multidão, os homens agiriam segundo uma espécie de mentalidade coletiva, a qual difere dos pensamentos e atitudes destes mesmos homens, caso estivessem isolados. Tudo seria culpa da "lei psicológica da unidade das multidões", que faria as massas, em uma multidão - perceba a falta de distinção dos termos para Le Bon -, serem detentoras de um caráter irracional, incivilizado. Ao contrário, cada homem, isoladamente, seria capaz de comportamento racional e discernimento.

\footnotetext{
${ }^{1}$ Professor na Faculdade Joaquim Nabuco e na Escola Superior de Marketing, Brasil. eloyzaidan@gmail.com
} 
0 professor-emérito da Faculdade de Filosofia, Letras e Ciências Humanas da Universidade de São Paulo (USP), Gabriel Cohn, ajuda a esclarecer onde reside, mais precisamente, o prisma conservador da obra do psicólogo e sociólogo francês, a qual,

Procura caracterizar a nova era histórica, de cuja emergência seria testemunha, ainda no período de 'transição e anarquia' que a precederia: a 'era das multidões'. Trata-se da 'entrada das classes populares na vida política'. É nesse ponto que a identificação entre multidões, massas e classes populares fica clara em Le Bon (COHN, 2014, p. 31).

Somente mais tarde, o sociólogo norte-americano Herbert Blumer (19001987) definiu formalmente o conceito de massa, atribuindo-lhe a pecha de uma modalidade de formação da sociedade, como 0 são 0 grupo, 0 público e a multidão.

É justamente a noção de massa - e o seu alcance - que abre o livro Sociologia da Comunicação: Teoria e Ideologia de Gabriel Cohn, que também é professor visitante sênior da Capes na Escola de Filosofia, Letras e Ciências Humanas da Universidade Federal de São Paulo (Unifesp). Trata-se de uma obra de "grande erudição" - nas apropriadas palavras do professor da Universidade Estadual do Rio de Janeiro, José Maurício Domingues -, o que pode tornar, é bom que se diga, a leitura um esforço hercúleo para o leitor menos experiente.

Honrosamente publicada ao lado de livros escritos por autores clássicos, como Émile Durkheim (1858-1917), Niklas Luhmann (1927-1998) e Pierre Bourdieu (1930-2002), dentre outros que integram a coleção Sociologia, coordenada por Brasilio Sallum Jr., da USP, Sociologia da Comunicação foi resgatada do limbo. Sua primeira edição remonta a 1973. Não é de se estranhar, portanto, que este título tenha se tornado uma raridade, mesmo em bibliotecas, pois teve que esperar até 2014 por uma nova edição.

Da primeira metade dos anos 1970 aos dias de hoje, muitas questões anacrônicas. Como aquelas alçadas à condição de problemas centrais do livro: "Como agem os meios de comunicação no plano coletivo? Quais os seus efeitos? 0 que significa falar em 'público' ou em 'massa'? Como a organização e o modo de agir desses meios se relacionam com diversos tipos de sociedades?” (COHN, 2014, p. 18). 
Gestada em um contexto de repressão política - a ditadura militar (19641985) -, a qual subtraiu da USP alguns de seus principais intelectuais, como Octavio Ianni (1926-2004), a obra é, evidentemente, anterior a revoluções como aquelas protagonizadas pelas chamadas novas mídias. Contudo, debruça-se sobre demandas conceituais cuja relevância é especialmente importante no atual contexto, em que as redes sociais, como o Facebook, estão alterando nossos padrões de relacionamentos.

Antes de mais nada, é importante frisar que Gabriel Cohn parece não endossar o conceito de massa como forma de sociedade, e tampouco como forma de comunicação, o que, de certa forma, já coloca o corpo teórico do professor brasileiro em um trilho que não é o de Blumer. Cohen (2014), convida o leitor a uma perspectiva de massa, "[...] na condição de situação no interior de sociedades [...]" (grifo do autor), conforme explica:

Refere-se a uma circunstância determinada, na qual o rompimento de laços sociais existentes ou a transição para novas modalidades de vínculos promove, por períodos mais ou menos prolongados, a emergência de algo que evoca a condição de 'estado de natureza' hobbesiano, na qual cada qual fica entregue à sua sorte a ao seu engenho enquanto não se encontra uma referência coletiva mais firme (COHN, 2014, p. 22).

No mais, tanto em 1973 como hoje, é inegável a importância da comunicação social - o que já torna profícua qualquer reflexão sobre o tema. É curioso notar o quão exótico, aos olhos da sociedade moderna, torna-se um sujeito alheio aos meios de comunicação. À televisão, ao rádio, ao cinema, se 0 contexto for os anos 1970. Ao Facebook, ao Twitter, ou, no mínimo, ao email, se 0 contexto for 0 atual. Chega-se ao ponto em que, "0 homem que ignora a notícia só passa a existir para a sociedade maior na qual vive, no mundo permeado pelos meios de comunicação, quando essa própria condição o converte em notícia." (COHN, 2014, p. 17).

Não por acaso, um certo Felipe, em um remoto interior de Minas Gerais, foi notícia na já finada revista Realidade, no já distante ano de 1971, por ignorar a viagem do homem à Lua. "Uai! Tem ilusão para tudo", teria dito. A reportagem inspirou a pesquisa de Cohn, a qual, por sua vez, redundou no livro Sociologia da Comunicação. Felipe nunca possuíra uma televisão - à época, a grande vedete das mídias, e já infestada por telenovelas. E já falava de ilusão. Com um pouco de esforço, talvez isto também pudesse ser mote para uma pauta de revista. 


\section{REFERÊNCIA}

COHN, Gabriel. Sociologia da comunicação: teoria e ideologia. Petrópolis-RJ: Vozes, 2014. 203 p. (Coleção Sociologia). 